\title{
The Importance of Imaging in the Diagnosis of Rectus Femoris Pyomyositis in a 35-Day-Old-Male Infant
}

\section{Otuzbeş Günlük Bir Olguda Rektus Femoris Piyomiyozitis Tanısında Görüntülemenin Önemi}

\author{
Nurdan Uraş ๑, İsmail Uraş ๑
}

Cite as: Uraş N, Uras İ. The importance of imaging in the diagnosis of rectus femoris pyomyositis in a 35-day-old-male infant. Forbes J Med. 2020;1(3): 105-9.

\begin{abstract}
Pyomyositis affecting the muscles around the hip may present with characteristics similar to those bof septic arthritis, which are challenging to diagnose due to their rare and vague presentation. Herein, we present a 35-day-old -male nfant with fever, restriction of hip and right limp movement and magnetic resonance imaging finding indicating rectus femoris pyomyositis.
\end{abstract}

Keywords: pyomyositis, rectus femoris muscle, septic arthritis

öz

Kalça eklemi kaslarını etkileyen piyomiyositis, nadir görülen septik artrit ile benzer klinik özellikler göstermektedir. Bu yazımızda septik artrit bulguları ile gelen magnetik rezonans görüntüleme ile rectus femoris piyomositis tanısı konulan 35 günlük bir olguyu sunmak istedik. Bu ölgu ile rectus femoris pyomyositisin tanısında görüntüleme yönteminin tanı, tedavi ve prognozu belirlemedeki önemini vurgulamayı amaçladık.

Anahtar kelimeler: piyomiyosit, rektus femoris kası, septik artrit
Received/Geliş: 11.10 .2020

Accepted/Kabul: 12.11 .2020

Publication date: 30.12 .2020 ersitesi Tıp Fakültesi Çocuk Sağlığı ve Hastalıkları Anabilim Dall, İstanbul - Türkiye nurdanuras@yahoo.com ORCID: 0000-0003-3382-7226

i. Uraş 0000-0001-9682-1767 Erdem Hastanesi, İstanbul, Türkiye 


\section{INTRODUCTION}

Pyomyositis is a suppurative and subacute bacterial infection of the involved muscles. It is primarily seen in increased incidence rates in tropical regions, with temperate climates. It has a critical importance, as it is not secondary to any other tissue infection. The etiology of this disease is still undefined. ${ }^{1-3}$ Any group of muscles can be involved; however, muscle groups around the pelvis and lower limbs may be frequently affected. For children, pyomyositis is generally seen between ages two and five and for adults 20-45 years old. Routine laboratory investigations are not specific to the case, and the diagnosis depends on imaging modalities. Magnetic resonance scanning is the most useful diagnostic tool and can detect early changes in the muscle. Treatment of pyomyositis includes relevant antibiotic therapy with/ without drainage..$^{1-3}$ Here, we present the clinical and magnetic resonance imaging of an infant with rectus femoris pyomyositis.

\section{CASE REPORT}

The patient was a 35-day-old boy who suffered from a 5-day history of fever, discomfort and restricted movements of his hip and right extremity. Any precipitating factors were not seen in this case. His physical examination revealed an axillary temperature of $38.2^{\circ} \mathrm{C}$, a heart rate of 128 bpm and a respiratory rate of $36 / \mathrm{min}$. The right hip was flexed; however, it was not abducted, yet its voluntary range of motion was reduced. Passive hip extension and flexion of the right hip were painful, and the flexion of the right hip was limited to $100^{\circ}$. The external and internal rotations were also restricted and painful. The remaining clinical examination findings were unremarkable. Analysis of some blood parameters within the first hour of his admission revealed that the erythrocyte sedimentation rate (ESR) increased to 35 Westergren units, C-reactive protein to 17 $\mathrm{mg} / \mathrm{dL}$ and white cell count to $10100 / \mathrm{mm}^{3}$. Radiographs of the lumbar spine, pelvis and right

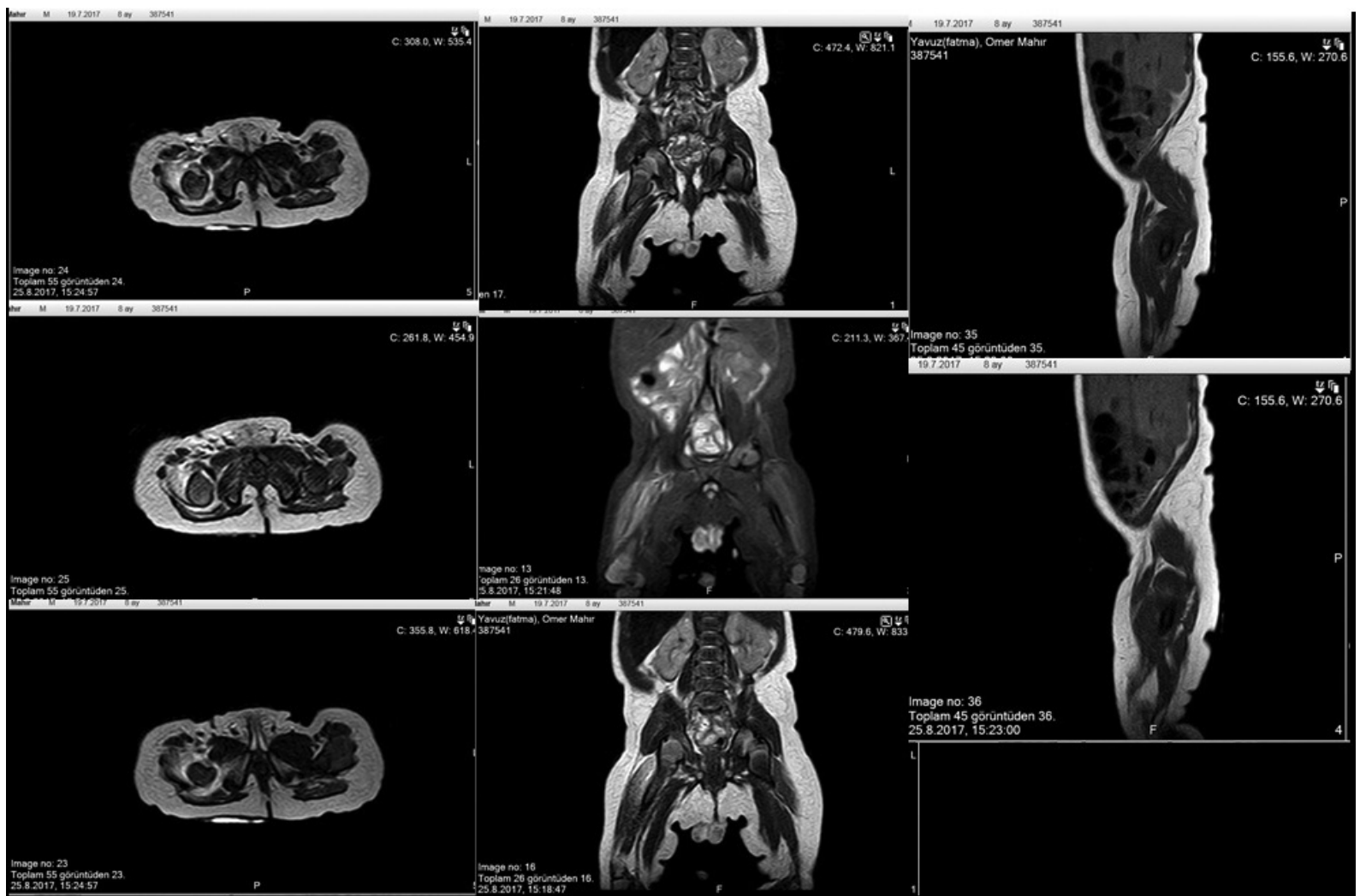

Figure 1. Synovial effusion at the right hip joint, rectus femoris from the right hip joint and till the mid-right femur, and inflammation signals at the rectus femoris and vastus lateralis muscle plans. 
hip were normal. Any pathogens were not identified in the blood culture and neither did ultrasound detect hip effusion or thickening of the periosteum. Synovial effusion was observed on the right hip joint in T1 coronal and T2 axial/coronal sections on magnetic resonance imaging. At the same time, inflammatory signals were detected on the planes of rectus femoris and vastus lateralis muscles in the area extending from the level of the right hip joint to the middle part of the right thigh. Bilateral femoral and acetabular joint surfaces were smooth and unimpaired. Because his symptoms persisted, and the inflammatory markers remained elevated, his antibiotic was subsequently changed to vancomycin four days after his admission to the hospital. Intravenous antimicrobial treatment continued for 14 days. He made good progress, with his CRP dropping down to less than $5 \mathrm{mg} / \mathrm{dl}$ and erythrocyte sedimentation rate to $16 \mathrm{~mm} / \mathrm{hr}$. At 8 week of his hospitalization, he was asymptomatic and his hip regained its full range of motion (ROM). The patient was conservatively treated with intravenous sulbactam-ampicillin $(100 \mathrm{mg} / \mathrm{kg} / \mathrm{d})$ plus amikacin $(15 \mathrm{mg} / \mathrm{kg} / \mathrm{d})$. Because his symptoms persisted, and the inflammatory markers remained elevated, the antibiotic regimen was subsequently changed to vancomycin $(20 \mathrm{mg} / \mathrm{kg} / \mathrm{d})$ four days later. A rapid clinical improvement was noted and pyrexia was not observed any further. The abscess was, therefore, not drained. Intravenous antimicrobial treatment continued for 14 days. He made good progress towards recovery with his CRP dropping down to less than 5 $\mathrm{mg} / \mathrm{dl}$ and ESR to 16 Westergren units. At eight weeks, he was asymptomatic and his hip regained its full ROM. The informed consent was obtained from the infant's parents for this case report.

\section{DISCUSSION}

The clinical findings and magnetic resonance imaging confirmed the diagnosis of primary pelvic pyomyositis in our newborn infant. Pyomyositis affecting muscles around the hip may be experi- enced as hip pain, however on rare occasions, either primary or secondary contiguous skin, bone or soft tissue infection may be observed. ${ }^{1}$ The etiology of the pyomyositis still remains unclear. However, it is stated that due to the trauma of the affected muscle and the following transient bacteremia, ${ }^{2,3}$ patients with immune deficiency and diabetes mellitus may predispose to pyomyositis. ${ }^{4,5}$ In our case, any particular demographic factors that suddenly became manifest were not detected.

Neonatal pelvic pyomyositis is by far less frequent than septic hip osteoarthritis. The presentation of pelvic pyomyositis shares similar traits with that of septic arthritis. Its clinical findings similar to those of other triggering conditions and its rarity together with its indolent presentation make the diagnosis of pyomyositis difficult. Routine laboratory assessments are nonspecific. In all cases, ESR and CRP elevate, as well as the white blood cell count, to more than $50 \%$ of the baseline values which are, in fact, relative characteristics noted for septic arthritis. ${ }^{1,6}$ Thus, clinicians encountering septic looking newborn with a decreased range of motion of the hip initially consider septic osteoarthritis as the working diagnosis. Therefore, clinicians who encounter septicappearing newborns with a reduced range of motion of hip initially consider septic osteoarthritis as a useful diagnosis. However, if ultrasound exam fails to detect periosteal thickening and particularly hip effusion, alternative diagnoses such as pelvic osteomyelitis or pyomyositis should be considered and further imaging studies need to be performed. Despite the septic appearance of our patient, any pathological finding was not detected in the hip ultrasonography. Thus, we considered that further imaging is needed for a conclusive and final diagnosis.

Imaging methods create the basis of diagnostic armamentarium. Plain radiographs are purposive for identifying other causes of diagnoses with different characteristics. Both computed tomography (CT) and ultrasonography have been used 
in the diagnosis of pyomyositis, and they also have the advantage of allowing percutaneous needle aspiration and drainage. Gadoliniumenhanced magnetic resonance imaging is the most useful imaging methodology more sensitive than CT that allows early recognition of widespread muscular inflammation and abscess formation. ${ }^{7,8}$ This method has many advantages including early diagnosis at the first stage, based on the existence of edema, treatment of the disease with earlystage curative antibiotherapy, and prevention of the disease without the need for surgical operation. ${ }^{7-10}$ We used MR for the differential diagnosis of our patient.

With early recognition of the disease and antibiotherapy, complete recovery is achieved without any complications. ${ }^{4,11,12}$ Factors affecting the treatment of pyomyositis include the stage of the disease, the etiological pathogen, the clinical course of the patient, and accompanying osteomyelitis. Antibiotic treatment alone may be sufficient in the early stages of the disease. ${ }^{8}$ The choice of antibiotics is variable but should include the coverage of $\mathrm{S}$. aureus and should be changed according to the susceptibility profile. The duration of intravenous antibiotic therapy reported in the literature ranges from 14 to 21 days. ${ }^{13-15}$ The antibiotic treatment of our patient was arranged as a sulbactam-ampicillin plus amikacin regimen so as to be effective also against $\mathrm{S}$. aureus strains. No bacterial growth was observed in the blood culture of our patient. However, on the fourth day of his treatment, vancomycin treatment was initiated due to the lack of any decrease in the levels of acute phase reactants without any improvement in the clinical course. After maintenance of antimicrobiotherapy for 14 days, improvement in clinical and laboratory results was observed. At the end of his treatment, the 8-week-old infant was well, and his clinical hip examination results were within normal limits.

In conclusion, early diagnosis of primary neonatal pelvic pyomyositis is difficult. Magnetic resonance imaging is warranted in patients with clinical features of septic hip osteoarthritis if ultrasound cannot detect hip effusion or periosteal thickening.

Conflict of Interest: The authors have no conflicts of interest to declare.

Informed Consent: Written informed consent was obtained from the parents.

\section{REFERENCES}

1. Kumar A, Anderson D. Primary obturator externus pyomyositis in a child presenting as hip pain: a case report. Pediatr Emerg Care. 2008;24(2):97-8. doi. org/10.1097/PEC.0b013e318163db2a

2. Viani RM, Bromberg K, Bradley JS. Obturator internus muscle abscess in children: report of seven cases and review. Clin Infect Dis. 1999;28:117Y122. doi.org/10.1086/515080

3. King RJ, Laugharne D, Kerslake RW, et al. Primary obturator pyomyositis: a diagnostic challenge. J Bone Joint Surg Br. 2003;85:895Y898. doi. org/10.1302/0301-620X.85B6.13824

4. Kiran M, Mohamed S, Newton A, George H, Garg $\mathrm{N}$, Bruce $\mathrm{C} 2$. Pelvic pyomyositis in children: changing trends in occurrence and management.Int Orthop. 2018;42(5):1143-7. doi.org/10.1007/ s00264-017-3746-1

5. Verma S, Singhi SC, Marwaha RK, Singhi P, Singh S, Singh M. J Trop Pediatr. Tropical pyomyositis in children: 10 years experience of a tertiary care hospital in northern India. 2013;59(3):243-5. doi. org/10.1093/tropej/fmt005

6. King RJ, Laugharne D, Kerslake RW. Primary obturator pyomyositis: a diagnostic challenge. J Bone Joint Surg Br. 2003;85:895Y898. doi.org/10.1302/0301620X.85B6.13824

7. Bickels J, Ben-Sira L, Kessler A, et al. Primary pyomyositis. J Bone Joint Surg Am. 2002;84:2277Y2286. doi.org/10.2106/00004623-200212000-00024

8. Spiegel DA, Meyer JS, Dormans JP, et al. Pyomyositis in children and adolescents: report of 12 cases and review of the literature. J Pediatr Orthop. 1999;19:143Y150. doi.org/10.1097/00004694199903000-00002

9. Verma S. Pyomyositis in Children. Curr Infect Dis Rep.2016;18(4):12. doi.org/10.1007/s11908-0160520-2

10. Tharmarajah $H$, Marks M. Early use of MRI for suspected pyomyositis. J Paediatr Child Health. 2015;51(6):651-2. doi.org/10.1111/jpc. 12916

11. Gubbay AJ, Isaacs D. Pyomyositis in children. Pediatr Infect Dis J. 2000;19(10):1009-12. doi. org/10.1097/00006454-200010000-00015

12. Mitsionis GI1, Manoudis GN, Lykissas MG, Sionti I, Motsis E, Georgoulis AD, Berisa AE. Pyomyositis in children: early diagnosis and treatment.J Pediatr 
N. Uraş and İ. Uraş, The Importance of Imaging in the Diagnosis of Rectus Femoris Pyomyositis in a 35-Day-Old-Male Infant

Surg. 2009;44(11):2173-8. doi.org/10.1016/j. jpedsurg.2009.02.053

13. Wong-Chung J,Bagali M,Kaneker S. Physical signs in pyomyositis presenting as a painful hip in children: a case report and review of the literature.J Pediatr Orthop B. 200;13(3):211-3. doi. org/10.1097/01202412-200405000-00013

14. Gubbay AJ, Isaacs D. Pyomyositis in children.
Pediatr Infect Dis J. 2000;19(10):1009-12. doi. org/10.1097/00006454-200010000-00015

15. Mitsionis GI, Manoudis GN, Lykissas MG, Sionti I, Motsis E, Georgoulis AD, et al. Pyomyositis in children: early diagnosis and treatment. J Pediatr Surg. 2009;44(11):2173-8. doi.org/10.1016/j. jpedsurg.2009.02.053 